\title{
The Interior Design of a Women's Health and Beauty Center with Postmodern Style in Surakarta City
}

\author{
Putri Widyaningrum, ${ }^{a, 1}$, Joko Budiwiyanto $b, 1^{*}$ \\ a Ki Hajar Dewantara Street No.19, Jebres, Kec. Jebres, Surakarta City, Central Java 57126. \\ 1 putri.widyan3@gmail.com; ${ }^{2}$ budiwiyanto.joko@gmail.com*; \\ * Corresponding Author
}

Received 21 April 2021; accepted 8 May 2021; published 13 June 2021

\begin{abstract}
The Interior Design of a Women's Health and Beauty Center in Surakarta City, precisely in a building of fitness and beauty center, applies a postmodern style. This design aims to create the interior design of a Women's Health and Beauty Center in Surakarta City which is able to facilitate all activity needs in comfortable and safe ways, and provides excellent beauty care and body fitness services. The interior design of a Women's Health and Beauty Center adopts Kurtz's programming method consisting of orientation stages, basic program creation, programming repetition, until the design reaches approval. The design foundation used is the aesthetic, ergonomic, and functional approaches. This design, with eclectic concept, is objected to gain attraction from the visitors by the creation of a space with a post-modern style that presents the theme of parang batik motifs. Surakarta's local wisdom in the form of such batik motifs aligned with modern elements with tropical nuances will answer the typical Indonesian comfort within several spaces, including: Main Lobby, Fitness Area Lobby, Gymnastics Studio, Fitness, Beauty Area Lobby, Whirlpool Room, Day Spa Room, Facial Treatment Room, Pedicure \&Manicure Room, and Sauna Room.
\end{abstract}

KEYWORDS

Design interior, Woman health Beauty center, Postmodern.

This is an openaccess article under the CC-BY-SA

license

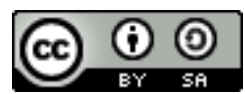

\section{Introduction.}

Working is an activity done to fulfill daily needs as a human-being. Sometimes, people do not pay attention to their body condition for being busy with all of daily activities (Deshayes et al. 2021). What they need, perhaps, is a special time and place to exercise, relax, and take care of their body to stay healthy, especially for women. Women are more prone to fatigue and even stress because of the busy routine in their daily basis (Chen et al. 2021). Not a few women doing more than one activity at the same time such as managing work and taking care of their family. Therefore, women have special needs body and beauty care for maintaining her health and their beauty as well.

Many women are interested in going to a body care center for their beauty and fitness. A place that prioritizes privacy for relaxation and women-only care is needed, where they can pamper the body without being worried of men during the treatment process going. Another thing that also makes the women feel comfortable could be various facilities that support their needs to look beautiful and healthy are just in one building.

Surakarta is a strategic city located in Central Java, that is close to other major cities such as Yogyakarta, Semarang, and Surabaya, still maintains its local wisdom as a special attraction for tourists. Surakarta, as a city of culture, is characterized by the existence of the Kasunanan and Mangkunegaran Palace. Life in the palace gives better chances for the palace relatives to have a plenty of time to think, create, develop, and preserve cultural arts, including the culture of nourishing their body and beautifying their appearance. The use of some herbs such as ratus (scented polyherbal preparation for beauty care), scrubs, mangir, boreh, balur , and so on, also some traditional drinks of mixed herbs made as jamu, is a way to nourish the body and beautify the appearance that comes from Javanese palaces. Thus, Surakarta city is very suitable and marketable for beauty and fitness centers, for being one of the major cities with a wide variety of activities that have potential in business and trade sectors. Additionally, in this city, there are various communities and events involving the activities of women. 
Based on the background description above, the interior design for "Women's Health and Beauty Center with Postmodern Style in Surakarta City" suits well. This design is made for one-stop facilities, as it provides facilities for both beauty and fitness as one package. The interior design goals of this building put several considerations on: (1) the customers, who are women, and prioritize those in their late teenagers to adult, (2) managers/employees who work to serve customers, as well as (3) experts in beauty and fitness involved in the service. The location of this design is planned to be not far from Pasar Kliwon area, where according to the Surakarta city spatial plan, serves as a center of the activities involving trade, goods and services, culture, tourism, and creative industries. An interior design with postmodern style in this article tries to bring local Javanese wisdom in the form of batik parang motif aligned with some modern elements of tropical nuances.

\section{Method.}

The stages of the design process in the interior design of the Woman Health and Beauty Center with postmodern style in Surakarta city adopted the Kurtz programming method consisting of four main stages, namely (Baskoro 2015):

1. Orientation stage. It is a stage of studying the philosophy, activities, and goals to achieve based on the results of discussions with clients.

2. Creating a basic program. This is the stage of assessing client needs, reviewing the supporting literature and initial plan of the program consisting of activities, space needs, space area, and space organization.

3. Repetition of programming. The designer presents the basic program to the client, and gets input or feedback from the client to be reviewed by the designer. This process continues to repeat until there achieves an agreement between the architect and the client.

4. Design stage. The designer presents the initial schematic design to the client, getting input from the client to be revised repeatedly until they reach an agreement. See Figure 1:

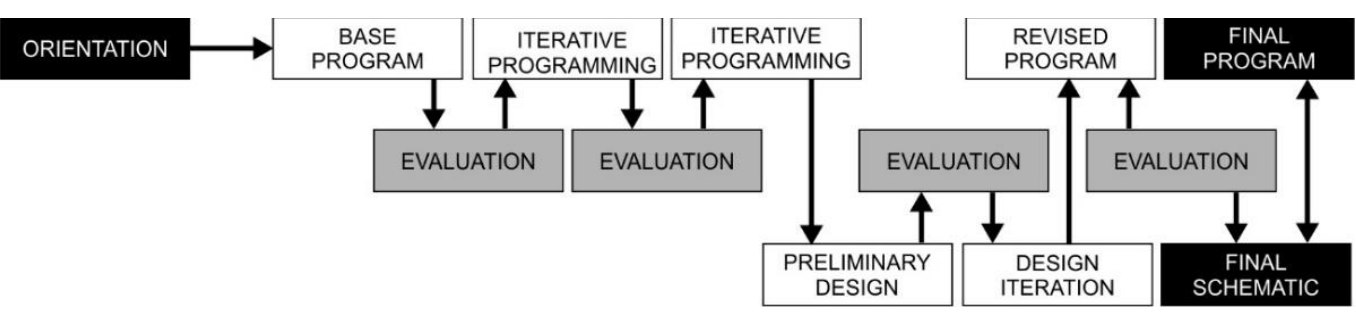

Fig. 1. Kurtz Programming Scheme (Baskoro 2015).

\section{Results and Discussion.}

The interior design of the women's health and beauty center in Surakarta city specifies in a building center where fitness and beauty service activities are designed by applying postmodern style (Joy and Venkatesh 1994). stated that physical fitness is the body's ability to do various activities well without experiencing significant fatigue. In addition, the body still has energy reserves that can be used at any time. Fitness Center is a place to improve the degree of health and physical fitness through physical exercise and exercise activities in a good, correct, measured and regular manner. Beauty, either as a sensory state or in deep meaning, invites to receive something good from the things, which encourages the soul to like and love it. What 'beautiful' means in several sources, one of them, is to look attractive with full majesty, with which women can lift their dignity and power. Being beautiful, by definition, reflects the natural beauty of God's gift and the beauty in man himself (inner beauty).

3.1. System and Service Procedures.

This health and beauty center service system includes: guest service of before, during, and post treatment service, healthy food and drink service, in accordance with sanitary hygiene requirements. The service standards can be explained in the following paragraphs. Guest service before treatment includes welcoming the arrival of guests, guest registration, providing information about the products and services provided, providing care consultations including identification of guest needs for care, types of care, treatment methods, and materials used for care. 
Service during treatment, consisting of water therapy (hydro therapy), aroma therapy (aroma therapy), using at least 10 (ten) types of essential oils original from Indonesia and at least 5 (five) types of non-Indonesian essential oils for muscle stretching (relaxation), skin rejuvenation (rejuvenation), and strengthening of body systems (revitalization). For massage therapy, there are at least 3 (three) types of traditional Indonesian massage and 2 (two) types of massage from other countries. There is also a natural therapy (herbal therapy), by soaking herbs, scrubs, and masks, uses at least 6 (six) types of herbs. Mind therapy includes: a. meditation; and b. muscle stretching or relaxation, music therapy or color therapy. There is also a heat therapy (thermal therapy). Some facial treatments (facial spa) use a machine or tool. Foot treatments (foot spa) and hand care (hand spa) are with tools and without tools. For hair and scalp treatment (hair and scalp spa) they can do either with tools or without tools. Then, for physical exercise, at least include: a. breathing exercises; b. stretching exercises; and c. yoga, Pilates or postural exercise exercises. Post-care services include: confirmation of care that has been given, provision of advice for home care; and advice for followup care. For the healthy food and drink service, it is in accordance with sanitary hygiene requirements.

\subsection{Organizational Structure.}

The organizational structure in the interior design of the women's bealth and beauty center is needed as a basis for determining the users, activities, space needs, furniture needs and some equipment. The following is the structure of the women's health and beauty center organization based on the literature obtained from various sources. See on figure 2.

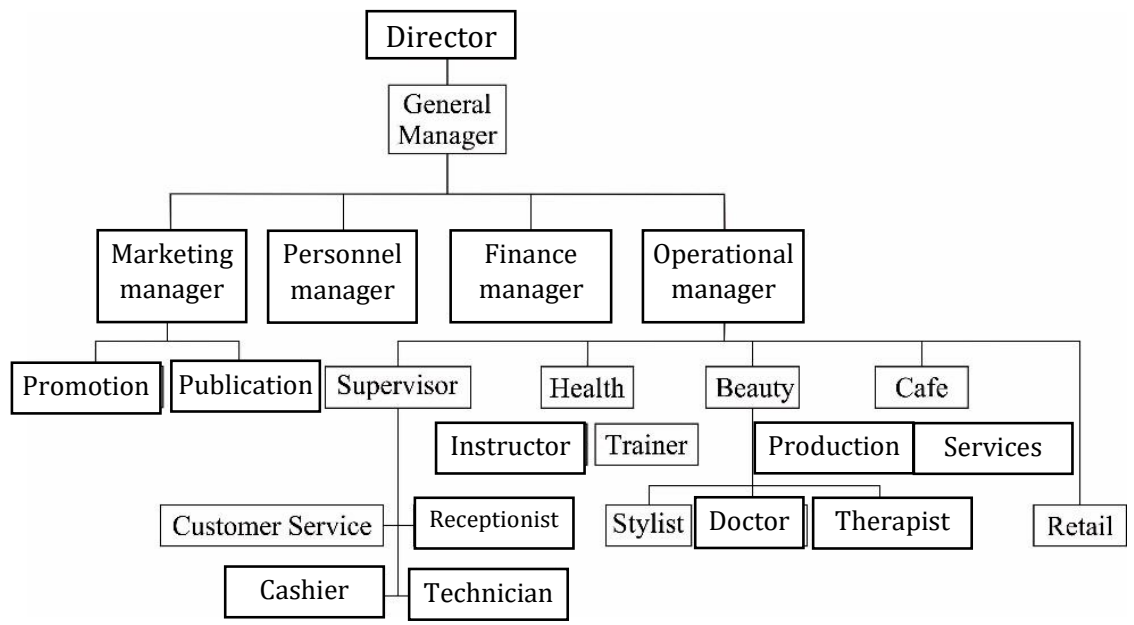

Fig. 2. The Organizational Structure of the Women's Health and Beauty Center

\subsection{Grouping dan Zoning.}

Grouping and zoning in interior planning are used to divide spaces by their nature, i.e. a) Public spaces are accessible to everyone (visitors, guests in general and managers); b) Semi-public space is a grouping of spaces in which contains activities that are not directly related to public areas (managers and guests / visitors); c) Private space is a grouping of spaces that demand a high level of privacy and is not related to the public; d) Service room is a space for services or supporting facilities. See on Figure 3. 


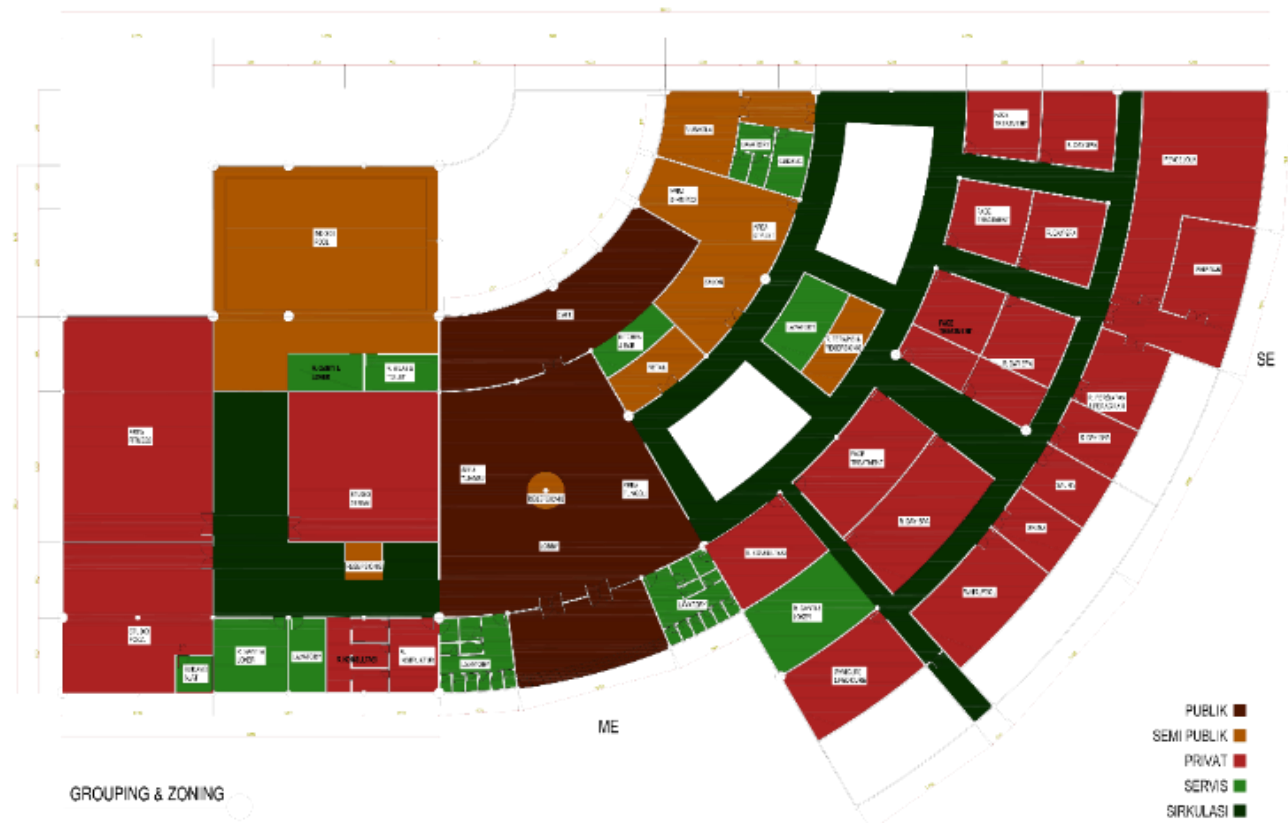

Fig. 3. Figure 3: Grouping and Zoning

\subsection{Circulation.}

Circulation in the interior design of the women's health and beauty center applies a linear circulation system that has a straight path, can be the main regulatory element for a series of spaces. These circulation lines can be linear or cut off, intersect with other paths, branches, or form a turning. Linear circulation can make it easier in terms of placing the room according to the function of space. Circulation that is taken into account in this design is the circulation of member visitors and new visitors, the officers, and goods. Meanwhile, the form of circulation flow scheme from the interior design of this woman health and beauty center that suits grouping - zoning is as follows.

\subsection{Theme and Style.}

The theme in the interior design of the women's health and beauty center with postmodern style is taken from the parang batik motif. Parang batik motif was once a prohibited motif, only allowed to be used by the relatives / circles of the palace. The philosophy of the parang batik motif is to describe weapons and power. As what is believed, the knights wearing parang batik can multiply their strengths. Besides, parang batik is also present on the costume of Srikandi, one of the wayang puppet figures, a beautiful female character that is popularly skilled, good at archery and such an example for other female soldiers. In this interior design, Srikandi is used as an icon that depicts beautiful and strong women in accordance with the entire image of this interior design. Batik motifs commonly used by kings and queens are applied to this interior design as a symbol that depicts customers to be served as like kings / queens. The application of the theme is taken from several shapes / motifs of parang batik. Batik motifs are taken as ornamental variety motifs on some parts of the wall, floor, ceiling, and so forth.

Local wisdom in the form of parang batik motifs is aligned with modern elements of tropical nuances. One of the characteristics of modern tropical design is to have a lot of green plants, either trees or low growing plants (shrubs), or in other words, very attached to nature and its elements. Some of the characteristics of postmodern architecture are: containing communicative elements that are local in nature, reawakening historical memories with the use of classical elements in buildings combined with modern patterns, applying technical ornamentation, and trying to present again the technical ornamentations which are opposed by the flow of modernism in the design of the building by combining modern elements, and is eclectic in nature. Postmodern streams tend to use soft or pastel colors, although for sure such rule doesn't exist. 
Postmodern style with the theme of parang batik motif in this design can be created through the selection of modern materials (glass, stainless steel, HPL, plywood), plants and materials that reflect tropical elements (wood, rattan, natural stone), as well as the combination of traditional elements (gebyog, tebeng, wood panels, tegel, and so on). The selection of materials from nature that support the tropical atmosphere in this design is to provide calm and comfortable feels, and can optimize the space function. Based on the description above, the following ideas are present, showing a transformation of the interior design of the women's health and beauty center in the style of postmodern.

\subsection{Layout.}

The basis of placing furniture as good as possible is to be arranged systematically in accordance with work patterns or work affairs to make it easier for the users to do their activities effectively and efficiently (Ching 1996), (Vargas and Stevenson 2014). In addition, the layout of the furniture needs to consider the functions and aesthetics of the space. The following is the result of arrangement of the layout and furniture in the interior design of the women's health and beauty center in Surakarta. This arrangement is in adjusted with the function of each space based on the activities of its users. The results of layout arrangement can provide comfort, support the safety of its users, and provide convenient access in every room according to its function. See on figure 4.

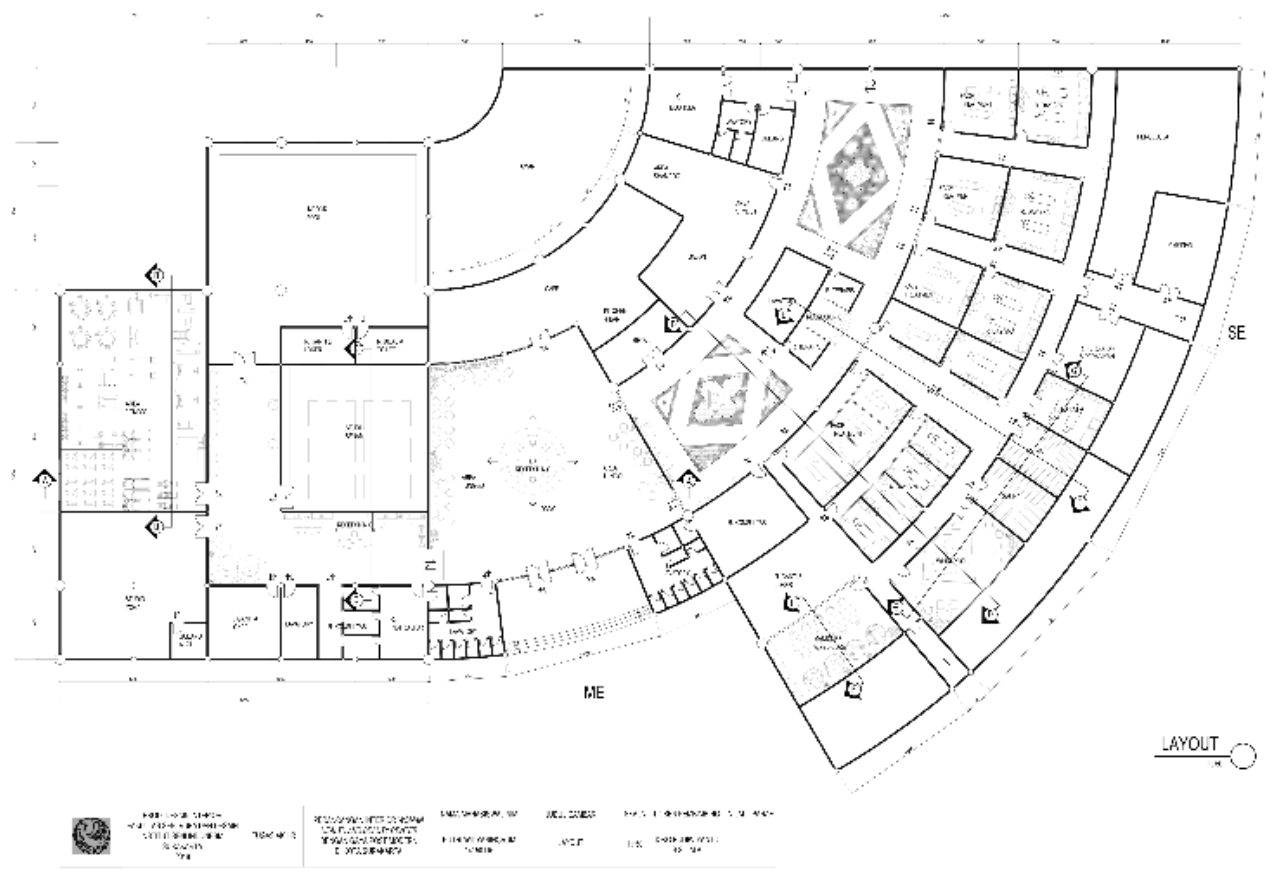

Figure 4. Laoy out.

\subsection{Space Filling Elements.}

On the furniture designs, the shape / motif of parang batik is present. For example, a parang motif, which is sloping or $45^{\circ}$ diagonal in shape, arranged repeatedly, forming a line applied as a variation or accent in the design of the reception desk. Here are some examples of furniture designs used in the interior planning of the women's health and beauty center. See on Figure 4. 

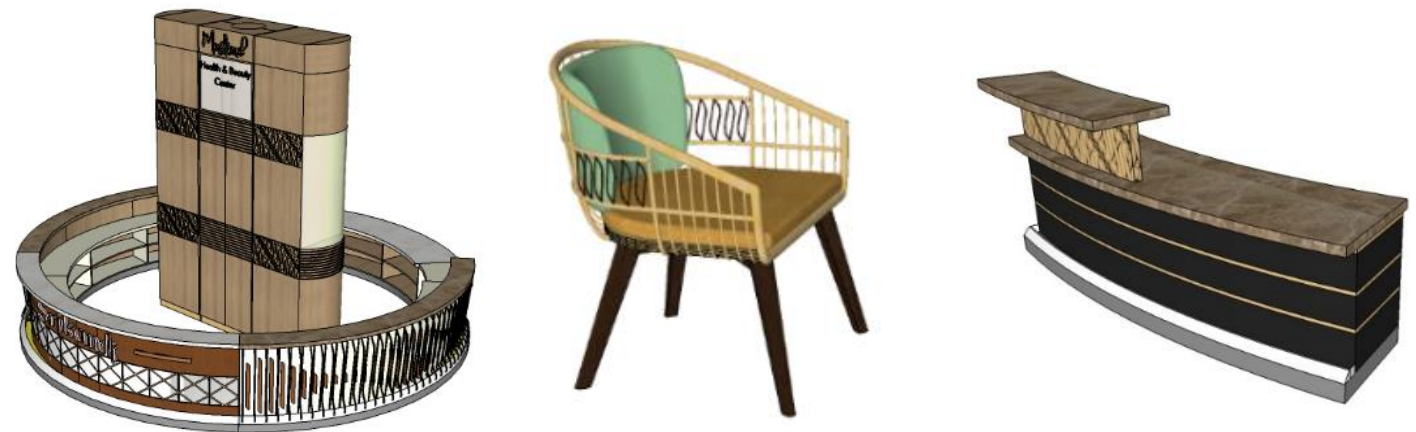

Fig. 4. Furniture.

Surakarta batik motifs representing Javanese elements are used on the hidden lamp accessories on the walls. Traditional Javanese chandeliers are used in some rooms to show historical impressions from the past. Flower vases and jars that have arches, with fine textures give a feminine impression. Tropical nuances in the room will be strengthened by the presence of plants in the vase. Here are some interior accessories used in the interior design of the Women's Health and Beauty Center.

\subsection{Space Conditioning.}

Space conditioning system in any interior environment is an important element of every building because it settles the arrangement of the air, visuals, sound and discharge needed for users' comfort and ease. In the interior design of the Women's Health and Beauty Center, artificial conditioning is more dominant (Moore et al. 2021). Fans are only used to speed up air circulation without reducing the degree of humidity, while air conditioners can regulate the speed of the airflow, temperature, humidity, and clean air distribution. The type of AC used in this design is Split AC. Split Air Conditioner is an indoor air conditioner that is installed on the wall to filter dirty air and take the clean air in. Natural conditioning is also applied in this design through ventilation, tebeng or grille above the door or windows. In addition to saving energy, the use of ventilation is very useful as a means of the entry of fresh air from the indoor garden next to the room.

The lighting system used in the interior design of the Women's Health and Beauty Center includes natural and artificial lighting. Natural lighting is from the sky light and some parts of the walls made of glass material as a window that cannot be opened (dead window) to let the light from the sun and moon enter the room. The types of artificial lighting used are general lighting, accent lighting, task lighting, and decorative lighting.

\subsection{Space Interior Concept.}

Space-forming elements in interior design include floors, walls, and ceilings. Floors tend to set the interior tone whether inside the home, office, or mall. Although aesthetics plays an important role in any design solution, flooring should be practical in today's environment. Today's designers have a range of floor types, colors, and patterns to choose from. Materials, colors, or patterns can be used as a sign of differences in terms of the function of a room. The floor material used in the interior design of Women's Health and Beauty Center is more dominant in granite tile, because the smooth texture can make a person feel calm and relaxed. The type, nature, and character of a floor are very influential on its function and must be adjusted to the needs of the space. Floor patterns are used as directions or flow circulation and to avoid the monotonous impression.

Walls are important element of design schemes because they define space, separate activities, and mark personal domains within a home or office. Wall material in the interior design of Women's Health and Beauty Center is more dominant in the use of pastel color paint finishing walls. Some rooms use different materials, such like the application of exposed rocks, to accentuate tropical nuances and walls with wood material (gebyog) as a Javanese element. The application of the theme of parang batik motif (Rangkuti, Rasjid, and Santoso 2015)on the wall is 
taken from batik motifs used by palace relatives / circles as motifs of wall ornamental variety in some rooms.

Ceiling serves as under-the-roof cover indoors, and is possible to create a certain impression to fulfill various kinds of space functions beside the material used. Ceiling material in the interior design of the Women's Health and Beauty Center is more dominantly using gypsum. In some rooms such as receptionist, waiting room, massage room, facial room, and café, there are variations in terms of level and ceiling patterns. Gypsum finishing uses bright-colored wall paint. In addition, there is a ceiling with wood material in certain areas to present tropical Javanese elements. The following is an analysis of the results of the design of space-forming elements in the interior design of the Women's Health and Beauty Center.

The main lobby is designed luxuriously with more accentuating postmodern style that combines Javanese and tropical modern(Park and Oh 2013) elements to make the lobby as a transition area, for public, accommodate the activities of customers who: come to find information, do member registration, or queue in line for waiting. The floor in the main lobby uses a combination of materials, namely, plain tile $20 \times 20 \mathrm{~cm}$, tile motif $20 \times 20 \mathrm{~cm}$, Nero Marquina marble 240x120 cm, Breccia Oniciata marble 240x120 cm. Tile materials support themes and styles. Marble material has a luxurious impression. The combination of materials supports the function of space as the first space entered by space users. The pattern created from the combination of materials makes it a point of interest in the lobby area. Floor patterns can also help direct and regulate circulation flow. Gebyok and tebeng walls serve as traditional Javanese elements (Budiwiyanto 2009). Windows or partitions with parang motifs support the theme and style of design. The use of gold color can create an elegant and luxurious impression. On the glass windows at the main door, there is a parang batik motif as a sun glass and decorative accent. Ceiling uses gypsum board material with a pink, green, and gold paint finish; plywood with white paint finish; wooden frame with natural brown coat; and a styling of wooden profiles in natural brown coat. How design of the central part plays with ceiling even makes it look interesting. The up ceiling pattern adopts the form of a traditional Javanese of tumpangsari combined with a circle pattern without saka guru. The combination of materials and ceiling patterns supports themes and styles. The existence of a typical Javanese chandelier even strengthens the theme and style.

The lobby or reception of the fitness center is used for the cashier and fitness reservation facility. Floor materials in the health lobby include plain tile $20 \times 20 \mathrm{~cm}$, tegel tile motif $20 \times 20 \mathrm{~cm}$, and White Onyx marble 240x120 cm. The use of tegelsupports the theme and style, while the type of white marble gives the impression of clean and luxurious. The combination of materials used supports the function of space. The roster wall with parang motif is applied to support the theme. Soft colors combined with gold decorative accents seem clean and feminine. The ceiling uses gypsum board material with white paint, a styling of wooden profile with natural brown coat, up ceiling wood with duco finishing in green and gold color supports the theme and style. The up ceiling pattern adopts the form of tumpang sari of a traditional Javanese house without saka guru. The variations of up ceiling and down ceiling make it look more interesting. See on Figure 5.
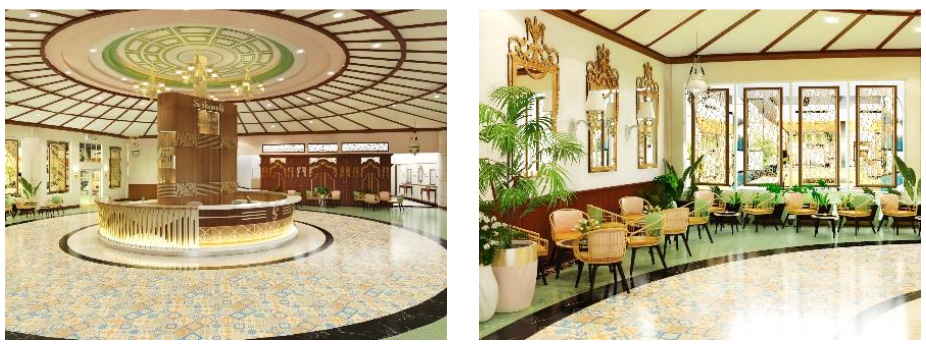

Fig. 5. Lobby.

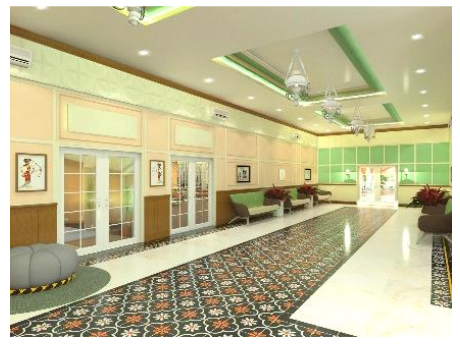

Sing

Fitness is very beneficial for women, to form an ideal body, nourish their heart organ, prevent osteoporosis, and reduce stress. The floor in the fitness area uses rubber gym material. It has a function that can provide a gentle effect like rubber conditions, preventing coldness on the floor 
when used, anti-slippery so as to support the function of the space. Gym rubber material is easy to install and clean. Roster walls patterned with kawning batik pattern as a partition as well as decorative elements can support the theme and style. Wide mirrors support the function of space. Artwork fitness serves as a support for activities and decorative elements. Ceiling used is from gypsum board material with white paint finish. Rose gold colored copper plates as accents on the ceiling can give the impression of elegance. A simple ceiling pattern supports the function of space so that it does not interfere the users' concentration.

Gymnastics studios are designed for aerobic activities, floor gymnastics, zumba, rhythmic gymnastics, and so on. Some of these exercises are beneficial for the flexibility of all parts of the body and can train the body to cope with stress, depression, fatigue, back pain, and so on. The floor material in the gymnastics studio is solid teak parquet measuring $60 \times 60 \mathrm{~cm}$ coated in natural brown. The arrangement of woods forms a pattern so that it does not seem monotonous. Solid wood material is rigid, hard, and strong against the footing. This natural material seems warm and luxurious. Wood is a porous material that absorbs sound and supports the function of space. The material panel walls with kawnng motif gypsum support the theme and style. Wide mirrors support the function of space. Ceiling material uses a gypsum board with a white paint finish so that it seems clean. A simple ceiling pattern supports the function of space so that it does not interfere with the users' concentration.

The lobby or receptionist of the beauty center is for both cashier and reservation of beauty facilities. The floor used is granite tile palazzo (Mirror Monza) 60x60 cm and 20x20 cm tile material. Granit tile Palazzo (Mirror Monza) gives the glamour impression. The combination of granite and tegel (floor tile) supports the style and function of space. Bright wall colors are used so that the room does not look narrow. Soft colors combined with gold decorative accents seem clean and feminine. Ceiling uses gypsum board material with white paint and there is sky light with asabi glass material in the indoor garden area to support the atmosphere. The selection of design patterns and gypsum board materials makes the room seem clean. The existence of a drop ceiling is used as a clue to the reception / cashier area.

Facial treatment rooms include the rooms of private (each for one person) and collective (several people in a room). The floor used in this room is a granite tile palazzo (Mirror Pallermo) $60 \times 60 \mathrm{~cm}$. Granite material is rigid, hard, strong against the footing, and easy to clean. Soft colors on glossy granite give the impression of cleanliness and elegance. There is a large mirror on the wall giving a broad impression on the room. Wall panel with kanung motif on gypsum material supports the theme and style. The selection of wall lamps and mirror shapes reinforces the theme. The ceiling material in the facial treatment room is gypsum board with white paint finish, wood paneling in natural brown coat, up ceiling gypsum board with finishing of brown- and gold-colored batik motif. Ceiling pattern is taken from the motif ornaments of parang batik to support the theme and style.

The day spa room accommodates activities including massage therapy treatments, beauty acupuncture, milk baths, and spices (herbs). The floor used is granite tile palazzo (Mirror Pallermo) $60 \times 60 \mathrm{~cm}$. Granite material is rigid, hard, strong against the footing, and easy to clean. Soft colors on glossy granite give the impression of clean and elegant. Large mirrors on the walls give the impression of spaciousness in the room. Wall panel with kawnung motif and gypsum material supports the theme and style. Marble material is used on areas that may be exposed to wetness or water. Brightly colored marble makes the room look clean and luxurious. The wall partition of parang motif uses brass material so that it supports the theme. The ceiling material is gypsum board with white paint finish, wooden frame with natural brown coat, duco gold and pink. The selection of design patterns and gypsum board materials gives a clean impression. See on Figure 6. 

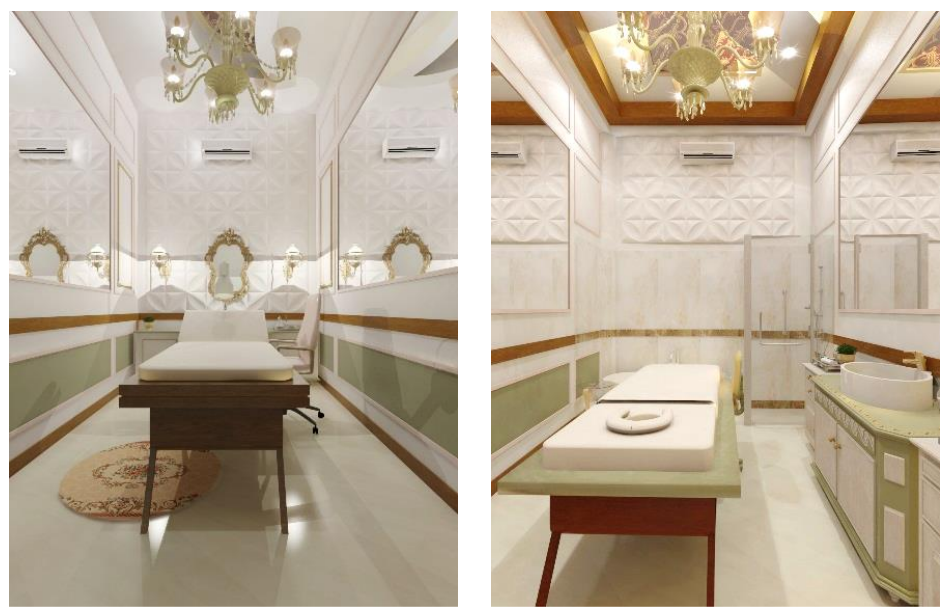

Fig. 6. Face treatment and day spa.

Pedicure is a treatment of the feet while manicure is hands treatment. The floor in the manicure and pedicure room uses granite tile salsa pearl white and black $60 \times 60 \mathrm{~cm}$. The blend of granite salsa pearl white and black gives the impression of cleanliness, feminine, and elegance (Jiang et al. 2022). The floor pattern of granite material supports the function of space. The wall uses wallpaper material with a parang motif supporting the theme. Soft wall colors combined with gold decorative accents give a clean and feminine impression. The material used on the ceiling is gypsum board with white paint finish, the gypsum board with brown and gold batik motif finishing. The selection of gypsum board material gives a clean impression. Ceiling pattern is taken from the basic shape of some parts of the parang batik motif so that it supports the theme and style.

Water therapy treatment room with whirlpool is a room for activities aimed at muscle stretching (relaxation), skin rejuvenation, and strengthening of the body system (revitalization). The floors used in the whirlpool room are granite tile salsa pearl stone black and white $60 \times 60 \mathrm{~cm}$. The combination of black and white textured granite tile is not too slippery so it supports the function of space. The walls using palimanan stone material which give a tropical impression. The relief of paras stone as a decorative element supports the theme and atmosphere. Natural stone material was chosen to give a natural and cold impression. The material on the ceiling of this room is wooden board and frame with a natural brown coat and white duco paint and a wooden board with a white duco finish. The white color is chosen to give a clean impression. Ceiling shapes or patterns support styles and concepts. The blending of all the materials used can create a tropical feel.

Sauna room is a place for steam bath activities, one of the ways to take care of the health of the body. The floor material used is solid teak parquet measuring $60 \times 60 \mathrm{~cm}$ with a natural brown coat. The arrangement of woods forms a pattern so that it does not seem monotonous. Wood is a material that is rigid, hard, strong against the footing. This natural material feels warm and looks luxurious. Wood is a porous material that absorbs sounds and supports the function of space. Walls with parangpatterned panels as heater covers can support the theme. Wood paneling material throughout the wall surface supports the function of the space. Ceiling material board and wooden frame with natural brown coat is very supportive and maximizes the function of space. This natural material(Ashby 2021) can also create a warm impression of the space.

\section{Conclusion.}

The interior design of Women's Health and Beauty Center with Postmodern Style in Surakarta City is a special place that accommodates service activities as a place for women to do body care comfortably because it prioritizes privacy (Guo et al. 2021). It is projected as a building that combines facilities for beauty and fitness in just one place. This design is expected to create interior design that can meet all activity needs comfortably and safely, provide excellent beauty care and body fitness services. Facilities accommodated in this design, are: gymnastics studio (for aerobic activities, Pilates, floor gymnastics, zumba, and rhythmic gymnastics), yoga studio, fitness, indoor pool, sauna, water therapy treatments with whirlpool, day spa, facial, hair care, feet care (pedicure) and hand care (manicure). Meanwhile, some additional facilities of this design are retail body care products, as well as café that provide healthy food and drinks to support beauty and fitness. 
The interior design of the Women's Health and Beauty Center in Postmodern style is created through the selection of materials, textures, colors, design shapes, comfort and privacy, lighting, and conditioning from the interior. The final design is expected to be able to attract visitors through the application of postmodern style. Postmodern style in this design shows the combination of traditional, modern, and tropical styles to bring historical value and impression to the interior. The application of traditional Javanese style on the walls, are: gebyog, tebeng, wood paneling; tiled floors; tumpangsari ceilings or wooden boards, and so on. Modern elements are taken from the application of glass, copper, plywood, and HP materials. Tropical elements are taken from the use of natural stone materials, wood, rattan, as well as adding ornamental plants to the room. The application of the theme is taken from several shapes / motifs of parang batik. Batik motifs are taken as ornamental motifs on some parts of the walls, floors, ceilings, furniture, and interior accessories. The theme of parang batik motif as the local wisdom of Surakarta is aligned with modern elements of tropical nuances in accordance with the Indonesian climate. The design that includes Javanese elements in the modern era can be a special place that answers the needs of the community in taking care of their body with the concept of aesthetic approach, ergonomics, and function.

\section{References}

Ashby, Michael F. 2021. "Renewable Materials, Natural Materials." In Materials and the Environment, 267-94. Elsevier. https://doi.org/10.1016/B978-0-12-821521-0.00011-6.

Baskoro, Satyo. 2015. "Metode Pemrograman John M. Kurtz." Prezy. 2015. https://prezi.com/iOuaulk42k-u/metodepemrograman-john-m-kurtz/\#: :text=Skema Pemrograman Kurtz\&text=Merupakan tahap pengkajian filosofi\% $2 \mathrm{C}$,klien berdasarkan konsultasi dengan klien.\&text=Proses ini menyajikan desain awal,terus menerus hingga tercapainya.

Budiwiyanto, Joko. 2009. "Penerapan Unsur-Unsur Arsitektur Tradisional Jawa Pada Interior Public Space Di Surakarta." Gelar: Jurnal Seni Budaya 7 (1).

Chen, Ming, Bin Ran, Xiaoying Gao, Guilan Yu, Jing Wang, and J. Jagannathan. 2021. "Evaluation of Occupational Stress Management for Improving Performance and Productivity at Workplaces by Monitoring the Health, WellBeing of Workers." Aggression and Violent Behavior, November, 101713. https://doi.org/10.1016/j.avb.2021.101713.

Ching, Francis DK. 1996. Ilustrasi Desain Interior. Jakarta: Erlangga.

Deshayes, Maxime, Karine Corrion, Raphaël Zory, Olivier Guérin, Frédéric Chorin, and Fabienne D’Arripe-Longueville. 2021. "Relationship between Personality and Physical Capacities in Older Adults: The Mediating Role of Subjective Age, Aging Attitudes and Physical Self-Perceptions." Archives of Gerontology and Geriatrics 95 (July): 104417. https://doi.org/10.1016/j.archger.2021.104417.

Guo, Michael Y., R. Trafford Crump, Ahmer A Karimuddin, Guiping Liu, Matthew J. Bair, and Jason M. Sutherland. 2021. "Prioritization and Surgical Wait Lists: A Cross-Sectional Survey of Patient's Health-Related Quality of Life." Health Policy, December. https://doi.org/10.1016/j.healthpol.2021.12.006.

Jiang, Ao, Bernard H. Foing, Irene Lia Schlacht, Xiang Yao, Vien Cheung, and Peter A. Rhodes. 2022. "Colour Schemes to Reduce Stress Response in the Hygiene Area of a Space Station: A Delphi Study." Applied Ergonomics 98 (January): 103573. https://doi.org/10.1016/j.apergo.2021.103573.

Joy, Annamma, and Alladi Venkatesh. 1994. "Postmodernism, Feminism, and the Body: The Visible and the Invisible in Consumer Research." International Journal of Research in Marketing 11 (4): 333-57. https://doi.org/10.1016/01678116(94)90011-6.

Moore, Matthew J., Richard P. Tan, Nianji Yang, Jelena Rnjak-Kovacina, and Steven G. Wise. 2021. "Bioengineering Artificial Blood Vessels from Natural Materials." Trends in Biotechnology, December. https://doi.org/10.1016/j.tibtech.2021.11.003.

Park, Woo Hee, and Hye Kyung Oh. 2013. "A Study on the Type and It's Characteristics of Tropical Space Style in Southeast Asia." Korean Institute of Interior Design Journal 22 (5): 179-87. https://doi.org/10.14774/JKIID.2013.22.5.179. 
Rangkuti, Abdul Haris, Zulfany Erlisa Rasjid, and D. Junaidi Santoso. 2015. "Batik Image Classification Using Treeval and Treefit as Decision Tree Function in Optimizing Content Based Batik Image Retrieval." Procedia Computer Science 59: 577-83. https://doi.org/10.1016/j.procs.2015.07.551.

Vargas, Gloria A., and Fionn Stevenson. 2014. "Thermal Memory and Transition in Lobby Spaces." Energy Procedia 62: 502-11. https://doi.org/10.1016/j.egypro.2014.12.412. 